\title{
Prevalence, Antimicrobial Susceptibilities and Molecular Characterization of Enteric Bacterial Pathogens Isolated from Patients with Infectious Diarrhoea in Cairo, Egypt
}

\author{
Abdel-Nasser A. El-Moghazy, Mahmoud M. Tawfick* and Mahmoud M. El-Habibi \\ Microbiology and Immunology Department, Faculty of Pharmacy, \\ Al-Azhar University, Cairo, Egypt \\ *Corresponding author
}

\section{Keywords \\ Enteric bacteria, Antimicrobial resistance, Infectious diarrhoea, Plasmid profile.}

\section{Article Info}

Accepted:

18 March 2016 Available Online: 10 April 2016
Infectious diarrhoea continues to cause significant morbidity and mortality, particularly among children worldwide. This problem is especially acute in developing countries. This study aimed to determine the prevalence, antimicrobial susceptibilities and plasmid-profile based molecular characterization of enteric bacteria isolated from patients with infectious diarrhoea in Cairo, Egypt. A total of 465 bacterial isolates were isolated from 412 diarrhoea faecal specimens and swabs collected from children and adults patients presenting acute diarrhoea, during the period from December 2013 to December 2015, at three hospitals in Cairo, Egypt. The fecal specimens were cultured by conventional methods for enteric bacterial pathogens. The biochemically identified bacterial isolates were subjected to the antimicrobial susceptibility testing using Kirby-Bauer disc diffusion method. For multi-drug resistant (MDR) isolates, identification and antimicrobial susceptibility pattern was confirmed by the automated MicroScan Walkaway system. Plasmid DNA was isolated from MDR isolates and different profiles were assessed by agarose gel electrophoresis. It was found that $E$. coli represents the most prevalent bacterial species among isolates (46.7 \%), followed by $K$. pnemoniae (29.9 \%), $P$. vulgaris (14.3\%), Enterobacter spp. (5.3\%), P. mirabilis (4.4\%), Citrobacter spp. $(1.7 \%)$ and Shigella spp. (0.7\%). Isolates in this study showed high levels of multidrug antimicrobial resistance to the antimicrobials tested as $46.9 \%$ of isolates were MDR. The plasmid profile analysis revealed that plasmids were diverse and distributive among isolates, thus different patterns were detected. In conclusion, this study revealed that infectious diarrhoea is attributed to different bacterial species, with $E$. coli is the most prevalent one. Most of isolated enteric bacterial pathogens are MDR, which could be explained by the indiscriminate and widespread use of antimicrobial agents and the empirical antibiotic therapy in hospitals. The diverse patterns of plasmid profiles observed could be due to higher exposure of people to enteric bacterial pathogens in these places. Thus, regular surveillance for the etiological agents of infectious diarrhoea to monitor the changing epidemiology of these resistant bacteria is warranted. 


\section{Introduction}

Infectious diarrhoea is a major cause of morbidity and mortality especially among children worldwide. This disease represents an emerging problem in developing countries where adequate sanitation facilities are lacking (Sang et al., 2012). It is estimated in developing countries that more or less $25 \%$ of all deaths in children younger than five years old are associated with an acute infectious diarrhoeal disease (Putnam et al., 2004; Alikhani et al., 2013). In addition, travelers from developed countries must expect an incidence rate of travelers' diarrhoea above $20 \%$, while sometimes even exceeding $50 \%$ during a two weeks' stay in a developing country (WHO, 2014). Therefore, surveillance for the etiological agents of infectious diarrhoea is needed in developing countries in to better estimate the burden of this disease (GómezDuarte et al., 2010).

Different pathologic conditions may be associated with diarrhoea, while the most common causes being infections by enteric pathogens, including bacteria, viruses and parasites (Collins, 2007). Still, unfortunately, many cases of infectious diarrhoea are not properly diagnosed, either because they are mild and/or self-limiting, thus the patient does not seek medical interest, or because the medical and laboratory resources are not available, especially in developing countries (Qadri et al., 2005). In Africa, although regular investigations of diarrhoea have not been reported, the diarrhoea-specific mortality in children younger than five years of age has been estimated at about 106 per 1000 (Olowe et al., 2003). In Egypt, enteric infections associated diarrhoea remain the leading cause of morbidity among infants and young children, where the incidence of infection in children under age of 5 years was reported to be between 14.3 - $23.6 \%$ during the period from 1994 to 2005 (ElGilany and Hammad, 2005). However, earlier reports indicated that until 1979, diarrhoeal diseases accounted for approximately half of all childhood deaths in Egypt, partly because curative care was largely inappropriate (Miller, 1992).

The Enterobacteriaceae members are among the most important enteric bacterial pathogens with medical significance. Because of their medical importance, an extremely large number of enteric bacteria have been isolated and characterized. Pathogenic strains of Escherichia coli are common cause of acute infectious diarrhea, while enterotoxigenic E. coli and Shigella H44Tspp. are the most important enteric bacterial pathogens causing diarrhoea in childhood (Alikhani et al., 2013). Other enteric bacteria causing infectious diarrhoea include Enterobacter aerogenes and $E$. cloacae, which are opportunistic and only infect infants and those immunocompromised (Sang et al., 2012).

There has been some success in treatment of enteric infections and/or infectious diarrhoea using antimicrobial agents. However; the rapid development of multidrug resistance has become an increasingly emerging problem with serious consequences on public health (Sankaran, 2000; WHO, 2014). Indeed, many reports have described resistance of enteric bacteria to different commonly prescribed antimicrobial agents with increasing treatment failures, which could be explained by the high frequency with which antimicrobials are used empirically to treat these disease (Putnam et al., 2004). While intestinal carriage of MDR bacteria often persists for years without disease, these bacteria can occasionally cause bloodstream and urinary tract infection even in patients without 
healthcare-associated risk factors. In addition, these MDR bacteria are potential source of cross transformation and the possibility of horizontal gene transfer conferring resistance to other bacteria in the intestinal tract. This led to raised concern of enteric bacteria in the medical community, because these bacteria are associated with enteric infections and resistant strains represent potential risk for both individual and community (Huttner et al., 2013). Multidrug resistance of enteric bacterial pathogens is related to possessing high molecular weight plasmids, which could be transferred between bacteria. This transmissibility of resistance-mediated plasmids poses public health threat, which could be heightened if disseminated across countries by travelers (Chigor et al., 2010).

In this study, we investigated the prevalence, antimicrobial susceptibility patterns and plasmid-profile based microbial diversity of enteric bacteria isolated from patients with infectious diarrhoea in Cairo, Egypt.

\section{Materials and Methods}

\section{Study Population and Specimen Collection}

During December 2013- December 2015, a total of 412 diarrhoea faecal specimens and rectal swabs were collected from 412 patients with acute infectious diarrhea, during the early stages of the disease, attending to three hospitals in Cairo: Abu El-Resh Hospital for Children, Abbasia Tropical Hospital and El-Hussein University Hospital. The study group of patients $(n=$ 412) included 183 non-hospitalized patients and 229 hospitalized patients of different age groups. Among the 412 specimens and rectal swabs, $230 \quad(55.8 \%)$ were from children aged $\leq 5$ years old and 182 (44.2 $\%)$ from adolescents and adults patients.
Diarrhoea was defined following Sang et al. (2012) as at least three loose stools in 24 hours, or any number of watery stools. The diarrhoea faecal specimens were collected into sterile transparent wide mouthed bottles. Sterile cotton swabs were used to collect rectal swabs and transported to lab over a period of two hours in Cary-Blair transport medium. All collected specimens were processed in the same day of collection.

\section{Processing of Specimens}

Primary isolation was performed following the conventional methods for isolation of enteric bacteria utilizing culture media to recover the most predominant bacterial isolate. The media used for isolation included Selenite F broth, MacConkey agar, Eosin methylene blue and Xylose Lysine Deoxycholate (XLD) agar. The specimens were inoculated onto the culture medium by streaking for isolation. The plates were then incubated at $37^{\circ} \mathrm{C}$ for $24-48$ hours. The isolates were selected based on the colonial appearance and distinguishing characters.

\section{Bacteriological Investigation of Collected Specimens}

Isolated pure cultures of bacteria were subjected to various morphological and biochemical tests. All isolated bacteria were identified to the genus level and in some cases to the species level. Isolates were identified by microscopic, culture characteristics (macroscopic) and conventional biochemical methods as described by Wim and Konman (2006) and Murray and Baron (2007).

\section{Antimicrobial Susceptibility Testing}

The antimicrobial susceptibility testing of each isolate was carried out using Kirby- 
Bauer disc diffusion method (Bauer et al, 1966), following the National Committee for Clinical Laboratory Standards guidelines (CLSI, 2014). Discs of 16 diverse antimicrobial agents tested purchased from Oxoid (UK) were ampicillin (AMP), piperacillin (PRL), amoxicillin-clavulanate (AMC), cefazolin (KZ), cefepime (FEP), cefotaxime (CTX), ceftazidime (CAZ), cefuroxime (CXM), aztreonam (ATM), meropenem (MEM), gentamicin (GN), amikacin (AK), doxycycline (DO), ciprofloxacin (CIP), trimethoprimsulfamethoxazole (SXT) and chloramphenicol (C). The test was performed on Muller Hinton agar (Oxoid, $\mathrm{UK})$, the diameter of the zone of inhibition was compared with zone diameter interpretative chart of CLSI (2014) to determine the sensitivity of the isolates to diverse antimicrobial agents tested.

\section{Microscan Analysis of Bacterial Isolates}

The MicroScan WalkAway (Siemens Healthcare, Germany) automated system was used to confirm identification and assays the susceptibility of the tested isolates to a set of antimicrobial agents. The interpretation was based on rules contained within the MicroScan Lab Pro Information System (version 2.0).

\section{Plasmid Isolation and Plasmid Profile Analysis}

Pure isolates were inoculated into $5 \mathrm{~mL}$ Luria Berteni broth and incubated overnight at $37^{\circ} \mathrm{C}$ and $200 \mathrm{rpm}$. Plasmid DNA isolation was performed using commercially available plasmid isolation kit (QIAprep ${ }^{\circledR}$ Spin Miniprep Kit, QIAGEN, Germany) according to the manufacturer instruction. The extracted plasmid DNA was subjected to electrophoresis on a $0.8 \%$ agarose gel stained with ethidium bromide in a horizontal tank at $100 \mathrm{~mA}$ and $100 \mathrm{~V}$ for 60 minutes. DNA molecular weight marker GelPilot $1 \mathrm{~kb}$ Ladder, 9 fragments: 1000-10,000 bp (Qiagen, Germany) was loaded to compare DNA band sizes. After electrophoresis, plasmid DNA bands were visualized by UV-transilluminator. The patterns of plasmid DNA profile was then analyzed and compared among isolates.

\section{Results and Discussion}

Phenotypic and Microscan WalkAway technique identification of enteric bacterial isolates

Out of 412 diarrhoea faecal specimens and rectal swabs collected from children $\geq$ five years of age, adolescents and adults patients presenting acute diarrhea at three hospitals in Cairo, Egypt, a total of 465 bacterial isolates were recovered. The prevalence of different bacterial species among total isolates as well as in relation to age is shown in Table 1. E. coli and $K$. pneumoniae represented the most prevalent bacterial species isolated in this study with percentages of $46.7 \%$ and $29.9 \%$, respectively.

\section{Antimicrobial Susceptibility Patterns and Detection of MDR Isolates}

The antimicrobial susceptibility studies showed that an overall higher resistance profile of bacterial isolates in this study to ampicillin $(95.5 \%)$, piperacillin $(90.1 \%)$, trimethoprim-sulfamethoxazole $(66.7 \%)$, chloramphenicol (64.3\%), amoxicillinclavulanate $(59.4 \%)$ and gentamicin (55.9 $\%)$. On the other hand, isolates had low resistance frequency to meropenem (13.3 $\%)$, ciprofloxacin $(23.7 \%)$ and cefepim (36.3\%). The antimicrobial resistance profiles of isolates are listed in Table 2. The recovered bacterial isolates in this study showed high levels of multidrug resistance 
to the antimicrobial agents tested as 218 out of $465(46.9 \%)$ were described as MDR that were resistant to three or more classes of antimicrobial agents. Table 2 shows the prevalence of MDR isolates among all isolates of different bacterial species isolated in this study. More investigation was done by the automated system Microscan WalkAway technique, which showed that 9 out of $465(1.9 \%)$ were confirmed as extensively drug resistant (XDR) which are bacterial isolates remain susceptible to only one or two categories. This included four isolates of $E$. coli, four isolates $K$. pneumoniae and one isolate $P$. mirabilis.

\section{Plasmid Profile Analysis-based Characterization of MDR Isolates}

Plasmid profile-based molecular characterization was carried out on 40 selected MDR isolates of the most predominant bacterial species including 20 E. coli isolates and $20 \mathrm{~K}$. pneumoniae isolates. Thirty one $(77.5 \%)$ isolates showed detectable plasmid bands which were not less than $\sim 1 \mathrm{kbp}$ in size. The plasmid profiles found among tested isolates included 1 - 5 bands of different sizes. The sizes of the plasmids among $E$. coli isolates ranged from $1.2 \mathrm{kbp}$ to $5.3 \mathrm{kbp}$. The plasmid profiles among $E$. coli isolates included single plasmid band ( 8 isolates) with sizes ranging from of around $1.2 \mathrm{kbp}$ to $5.3 \mathrm{kbp}$; two plasmid bands (3 isolates) of sizes ranging from of around $1.2 \mathrm{kbp}$ to $5 \mathrm{kbp}$; three plasmid bands (2 isolates) of sizes ranging from of around $1.2 \mathrm{kbp}$ to $4 \mathrm{kbp}$; four plasmid bands (one isolate) of sizes ranging from of around $1 \mathrm{kbp}$, to $4 \mathrm{kbp}$; five plasmid bands (one isolate) of sizes ranging from of around 1.2 to $3.5 \mathrm{kbp}$; and 5 isolates showed no detectable plasmid bands. Among $K$. pneumoniae isolates, eight of the isolates had single plasmid band of different sizes ranging from around $1 \mathrm{kbp}$ to $3.5 \mathrm{kbp}$; three isolates possessed two bands with sizes ranging from $1 \mathrm{kbp}$ to $8 \mathrm{kbp}$; three isolates possessed three bands with sizes ranging from $1 \mathrm{kbp}$ to $5 \mathrm{kbp}$; one isolate possessed four bands with sizes ranging from $1 \mathrm{kbp}$ to $5 \mathrm{kbp}$; one isolate possessed 6 bands with sizes ranging from $1.5 \mathrm{kbp}$ to $5 \mathrm{kbp}$ and four isolates showed no detectable plasmid bands.

Infectious diarrhoea remains a major public health concern, representing the second most important cause of mortality in childhood in developing countries. It is estimated that 1.4 billion episodes of diarrhea occurs annually among children younger than five years worldwide, causing around 1.87 million deaths (Boschi-Pinto et al., 2008). Therefore, surveillance for the etiological agents of infectious diarrhoea is needed in developing countries to better estimate the burden of this disease (Gómez-Duarte et al., 2010). In this study, 412 diarrhoea fecal specimens and rectal swabs from three study hospitals in Cairo, collected between December 2013 and December 2015 from patients with infectious diarrhoea were analyzed. The patient groups included in this study are children less than five years old, adolescent and adults. The stool samples were analyzed by conventional cultural and biochemical methods, antimicrobial susceptibility testing and plasmid-profile analysis. In addition, for selected MDR isolates, further confirmation of identification and antimicrobial susceptibility was performed using the fully automated MicroScan Walkaway system.

A total of 465 isolates out of the 412 diarrhoea faecal specimens and rectal swabs were recovered as some specimens showed more than one predominant enteric bacterial isolate. By analyzing the prevalence of bacterial species, E. coli represented the most prevalent among isolates 217/465 (46.7 
$\%)$. In relation to age, E. coli was also the most predominant in both children and adult groups. This finding is in agreement with many studies that revealed high rates of isolation of $E$. coli from infectious diarrhoea (Hart et al., 1993; Jindale et al., 1995; Yah et al., 2007). In the 1940s, E. coli was incriminated in outbreaks of childhood diarrhoea, especially in nurseries (Carpenter, 1989). Since then, E. coli has found to be the most common cause of acute bacterial diarrhoea in children and neonates in developing countries (Hart et al., 1993). In an Indian study investigating enteric bacterial infections in diverse age groups, the predominant isolate was $E$. coli with percentage of $44.4 \%$ (Jindale et al., 1995). In a similar study was conducted in Nigeria, eight different bacterial species were isolated with E. coli $(41.3 \%)$ was the most predominant one and others included Shigella dysenteriae (17.4\%), Pseudomonas aeruginosa (9.2\%), Salmonella Typhi (8.3 $\%)$, Staphylococcus aureus (3.2\%), Proteus mirabilis (2.3 \%), Enterococcus faecalis $(11.5 \%)$ and $K$. pneumoniae $(6.9 \%)$ were isolated from diarrheal stool of paediatric patients (Yah et al., 2007). In a another study from Nigeria, E. coli was also found to be the most frequently isolated bacteria in all age groups with diarrhoea (62.6\%), however other bacterial species showed lower rates of isolation including Pseudomonas spp. (4.32 \%), Salmonella spp. (2.88 \%), Staphylococcus aureus (5.76 $\%)$, Proteus spp. (12.23 \%), Enterobacter cloacae (2.16\%), Shigella spp. (1.44\%) and K. pneumoniae (8.63\%) (Akinnibosun and Nwafor, 2015). Conversely, in the current study, we have not isolated any Shigella, Pseudomonas spp., Staphylococcus or Enterococcus bacteria from specimens collected from children. However, Enterobacter and Citrobacter bacteria were isolated from children's fecal specimens, and Shigella spp. was isolated only from adults. Notably, the panel of bacterial species isolated from children was the same as the panel of species isolated from adults group, except Shigella bacteria which isolated from adults only. This could be due to higher exposure of people in this region to the enteric bacterial pathogens.

Enteric bacterial pathogens are known to have multidrug resistance characteristics (Sankaran and Neeraja, 2000; WHO, 2014). This study demonstrated high resistance profiles of isolated enteric bacteria from patients in the three study hospitals. Although, earlier reports stated that ampicillin, chloramphenicol, tetracycline and aminoglycoside have distinct antibacterial activity against enteric bacterial pathogens (Brooks et al., 1991). The antimicrobial susceptibility studies in this study showed that an overall higher resistance profile of bacterial isolates to ampicillin (95.5\%), piperacillin $(90.1 \%)$, trimethoprim-sulfamethoxazole $(66.7 \%)$, chloramphenicol $(64.3 \%)$ and gentamicin $(55.9 \%)$. These findings suggested that these antimicrobial agents are not suitable for initiation of empirical treatment of enteric bacteria causing diarrhoea in the population of a developing country like Egypt. This may be explained by the overuse or misuse of these antimicrobial agents in developing countries which leads to an increase of resistance to them (Nguyen et al., 2005). On the other hand, isolates had low resistance frequency to meropenem (13.3\%), ciprofloxacin $(23.7 \%)$ and cefepim $(36.3 \%)$. This lower resistance rate could be attributed to the limited use of theses antimicrobial agents. In addition, isolates showed resistance rate of $53.3 \%$ to doxycycline. In consistent to our results, study of Akinnibosun and Nwafor (2015) showed high resistance rate of enteric bacteria to doxycycline. Tetracyclines have been progressively displaced by safer and 
equally effective drugs for the treatment of these conditions in which they are likely to be more effective. However, the benefits of therapy with a tetracycline can exceed the risks if alternative drugs which could be are associated with more significant side effects (Diniz-Santos et al., 2006). In a prospective diarrhoea surveillance cohort study of 1,034 infants of low socioeconomic communities in Lima, Peru to determine the prevalence and antimicrobial drug susceptibility of the diarrheagenic $E$. coli. The resistance frequencies to tetracycline was $65 \%$, to ampicillin was $85 \%$, to trimethoprimsulfamethoxazole was $79 \%$ (Ochoa et al., 2009).

Significantly, in the current study, meropenem, ciprofloxacin and cefepim were first, second and third effective antimicrobial agents against enteric bacterial isolates tested. From these findings, these antimicrobial agents may be considered as empirical therapy for infectious diarrhea and/or enteric infections in these hospitals.

Table.1 Frequency of Bacterial Species Recovered from Diarrhoea Faecal Specimens and Rectal Swabs in Relation to Age

\begin{tabular}{|l|c|c|c|}
\hline \multirow{2}{*}{ Bacterial species } & \multirow{2}{*}{$\begin{array}{c}\text { Total No. of } \\
\text { isolates } \\
\text { (Percentages) }\end{array}$} & \multicolumn{2}{|c|}{$\begin{array}{c}\text { Age groups of study population } \\
\text { No. of isolates (Percentages) } * *\end{array}$} \\
\cline { 3 - 4 } & $217(46.7 \%)$ & $136(51.7 \%)$ & $81(40 \%)$ \\
\hline E. coli & $139(29.9 \%)$ & $63(24 \%)$ & $76(37.6 \%)$ \\
\hline K. pneumoniae & $59(12.7 \%)$ & $37(14 \%)$ & $22(10.9 \%)$ \\
\hline $\boldsymbol{P}$. vulgaris & $18(3.9 \%)$ & $13(5 \%)$ & $5(2.5 \%)$ \\
\hline $\boldsymbol{P}$. mirabilis & $22(4.7 \%)$ & $12(4.6 \%)$ & $10(5 \%)$ \\
\hline Enterobacter spp. & $7(1.5 \%)$ & $2(0.7 \%)$ & $5(2.5 \%)$ \\
\hline Citrobacter spp. & $3(0.6 \%)$ & $0(0 \%)$ & $3(1.5 \%)$ \\
\hline Shigella spp. & 465 & 263 & 202 \\
\hline Total No. & & Adolescents and adults \\
\hline
\end{tabular}

*Percentage correlated to the total number of isolates. **Percentage correlated to the total number of isolates from children group or adolescents and adults group. $* * *$ Children aged $\leq 5$ years old

Figure.1 Agarose Gel (0.8 \%) Electrophoresis of Plasmid Profiles of Selected MDR E. coli Isolates. M, DNA Molecular Weight Marker, Lanes $1-10$ in each Panel, E. coli Isolates

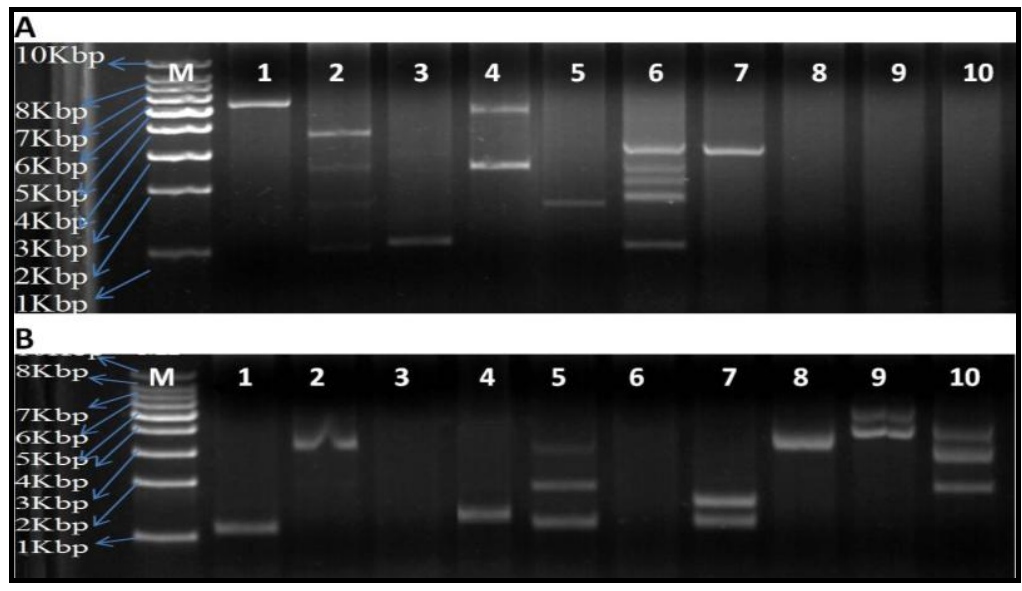


Table.2 Antimicrobial Resistance Profiles of Isolated Bacteria and Prevalence of MDR Isolates among Enteric Bacterial Species Isolated in this Study

\begin{tabular}{|c|c|c|c|c|c|}
\hline \multirow[b]{2}{*}{$\begin{array}{l}\text { Antimicrobial } \\
\text { agent* }\end{array}$} & \multicolumn{5}{|c|}{ Bacterial species (No. of isolates) } \\
\hline & $\begin{array}{l}\text { E. coli } \\
(217)\end{array}$ & $\begin{array}{c}\text { K. pneumoniae } \\
\text { (139) }\end{array}$ & $\begin{array}{c}\text { Proteus } \\
\text { spp. } \\
(77)\end{array}$ & $\begin{array}{l}\text { Enterobacter spp., } \\
\text { Citrobacter spp., } \\
\text { Shigella spp. (32) }\end{array}$ & $\begin{array}{l}\text { Total } \\
(465)\end{array}$ \\
\hline \multicolumn{6}{|c|}{ No. $(\%)$} \\
\hline AMP & $\begin{array}{c}202 \\
(93.1)\end{array}$ & $\begin{array}{c}133 \\
(95.7)\end{array}$ & $\begin{array}{c}77 \\
(100)\end{array}$ & $\begin{array}{c}32 \\
(100)\end{array}$ & $\begin{array}{c}444 \\
(95.5)\end{array}$ \\
\hline PRL & $\begin{array}{c}186 \\
(85.7)\end{array}$ & $\begin{array}{c}128 \\
(92.1)\end{array}$ & $\begin{array}{c}74 \\
(96.1)\end{array}$ & $\begin{array}{c}31 \\
(96.9)\end{array}$ & $\begin{array}{c}419 \\
(90.1)\end{array}$ \\
\hline AMC & $\begin{array}{c}120 \\
(55.3)\end{array}$ & $\begin{array}{c}80 \\
(57.6)\end{array}$ & $\begin{array}{c}68 \\
(88.3)\end{array}$ & $\begin{array}{c}8 \\
(25)\end{array}$ & $\begin{array}{c}276 \\
(59.4)\end{array}$ \\
\hline KZ & $\begin{array}{c}119 \\
(54.8)\end{array}$ & $\begin{array}{c}90 \\
(64.7)\end{array}$ & $\begin{array}{c}51 \\
(66.2)\end{array}$ & $\begin{array}{c}14 \\
(43.8)\end{array}$ & $\begin{array}{c}275 \\
(59.1)\end{array}$ \\
\hline FEB & $\begin{array}{c}78 \\
(35.9) \\
\end{array}$ & $\begin{array}{c}55 \\
(39.6) \\
\end{array}$ & $\begin{array}{c}28 \\
(36.4) \\
\end{array}$ & $\begin{array}{c}8 \\
(25) \\
\end{array}$ & $\begin{array}{c}169 \\
(36.3) \\
\end{array}$ \\
\hline CTX & $\begin{array}{c}91 \\
(41.9) \\
\end{array}$ & $\begin{array}{c}71 \\
(51.1) \\
\end{array}$ & $\begin{array}{c}36 \\
(46.8) \\
\end{array}$ & $\begin{array}{c}12 \\
(37.5) \\
\end{array}$ & $\begin{array}{c}210 \\
(45.2)\end{array}$ \\
\hline $\mathrm{CAZ}$ & $\begin{array}{c}77 \\
(35.5) \\
\end{array}$ & $\begin{array}{c}61 \\
(43.9) \\
\end{array}$ & $\begin{array}{c}24 \\
(31.2) \\
\end{array}$ & $\begin{array}{c}7 \\
(21.9) \\
\end{array}$ & $\begin{array}{c}169 \\
(36.3) \\
\end{array}$ \\
\hline CXM & $\begin{array}{c}112 \\
(51.6) \\
\end{array}$ & $\begin{array}{c}78 \\
(56.1) \\
\end{array}$ & $\begin{array}{c}41 \\
(53.2) \\
\end{array}$ & $\begin{array}{c}13 \\
(40.6) \\
\end{array}$ & $\begin{array}{c}244 \\
(52.5) \\
\end{array}$ \\
\hline ATM & $\begin{array}{c}122 \\
(56.2) \\
\end{array}$ & $\begin{array}{c}73 \\
(52.5) \\
\end{array}$ & $\begin{array}{c}32 \\
(41.6) \\
\end{array}$ & $\begin{array}{c}19 \\
(59.4) \\
\end{array}$ & $\begin{array}{c}246 \\
(52.9) \\
\end{array}$ \\
\hline MEM & $\begin{array}{c}30 \\
(13.8) \\
\end{array}$ & $\begin{array}{c}26 \\
(18.7) \\
\end{array}$ & $\begin{array}{c}4 \\
(5.2) \\
\end{array}$ & $\begin{array}{c}2 \\
(6.3) \\
\end{array}$ & $\begin{array}{c}62 \\
(13.3) \\
\end{array}$ \\
\hline $\mathbf{G N}$ & $\begin{array}{c}100 \\
(46.1) \\
\end{array}$ & $\begin{array}{c}91 \\
(65.5) \\
\end{array}$ & $\begin{array}{c}48 \\
(62.3) \\
\end{array}$ & $\begin{array}{c}21 \\
(65.6) \\
\end{array}$ & $\begin{array}{r}260 \\
(55.9) \\
\end{array}$ \\
\hline AK & $\begin{array}{c}81 \\
(37.3) \\
\end{array}$ & $\begin{array}{c}65 \\
(46.8) \\
\end{array}$ & $\begin{array}{c}32 \\
(41.6) \\
\end{array}$ & $\begin{array}{c}10 \\
(31.3) \\
\end{array}$ & $\begin{array}{c}188 \\
(40.4) \\
\end{array}$ \\
\hline DO & $\begin{array}{c}98 \\
(45.2) \\
\end{array}$ & $\begin{array}{c}78 \\
(56.1) \\
\end{array}$ & $\begin{array}{c}54 \\
(70.1) \\
\end{array}$ & $\begin{array}{c}18 \\
(56.3 \\
\end{array}$ & $\begin{array}{r}248 \\
(53.3) \\
\end{array}$ \\
\hline CIP & $\begin{array}{c}52 \\
(24) \\
\end{array}$ & $\begin{array}{c}33 \\
(23.7) \\
\end{array}$ & $\begin{array}{c}19 \\
(24.7) \\
\end{array}$ & $\begin{array}{c}6 \\
(18.8) \\
\end{array}$ & $\begin{array}{c}110 \\
(23.7) \\
\end{array}$ \\
\hline SXT & $\begin{array}{c}136 \\
(62.7) \\
\end{array}$ & $\begin{array}{c}83 \\
(59.7) \\
\end{array}$ & $\begin{array}{c}69 \\
(89.6) \\
\end{array}$ & $\begin{array}{c}22 \\
(68.8) \\
\end{array}$ & $\begin{array}{r}310 \\
(66.7) \\
\end{array}$ \\
\hline $\mathbf{C}$ & $\begin{array}{c}134 \\
(61.8) \\
\end{array}$ & $\begin{array}{c}82 \\
(59) \\
\end{array}$ & $\begin{array}{c}62 \\
(80.5) \\
\end{array}$ & $\begin{array}{c}21 \\
(65.6) \\
\end{array}$ & $\begin{array}{r}299 \\
(64.3) \\
\end{array}$ \\
\hline $\begin{array}{l}\text { No. of MDR } \\
\text { isolates }(\%)^{* *}\end{array}$ & $\begin{array}{c}94 \\
(43.3) \\
\end{array}$ & $\begin{array}{c}78 \\
(56.1) \\
\end{array}$ & $\begin{array}{c}37 \\
(48.1) \\
\end{array}$ & $\begin{array}{c}9 \\
(28.1)\end{array}$ & $\begin{array}{c}218 \\
(46.9)\end{array}$ \\
\hline
\end{tabular}

*AMP, ampicillin, PRL, piperacillin, AMC, amoxicillin-clavulanate, KZ, cefazolin, FEB, cefepime, CTX, cefotaxime, CAZ, ceftazidime, CXM, cefuroxime, ATM, aztreonam, MEM, meropenem, GN, gentamicin, AK, amikacin, DO, doxycycline, CIP, ciprofloxacin, SXT, trimethoprim-sulfamethoxazole, C, chloramphenico. **Percentage correlated to the total number of isolates of each bacterial species. 
Figure.2 Agarose Gel (0.8 \%) Electrophoresis of Plasmid Profiles of Selected MDR K. pnemoniae Isolates. M1, DNA Molecular Weight Marker, Lanes 1 - 10 in each Panel, K. pnemoniae Isolates

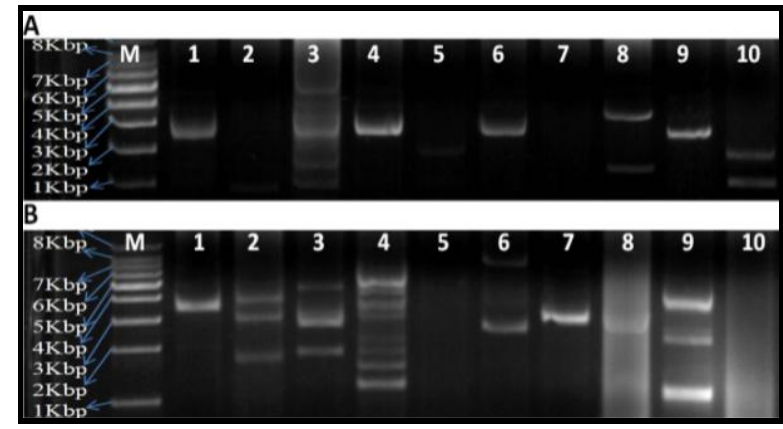

Multidrug resistance is defined as the nonsusceptibility to at least one agent in three or more classes of antimicrobial agents (Magiorakos et al., 2012). Following this definition, $218(46.9 \%)$ of the bacterial isolates in this study were described as MDR with higher percentage among $K$. pneumoniae isolates. Moreover, 9 isolates were described as XDR which are bacterial isolates remain susceptible to only one or two categories of antimicrobial agents. The extensive use of antimicrobial agents in treating infections in developing countries has led the emergence and spread of antimicrobial resistance in bacteria of medical importance (Temu et al., 2007). Thus, regular antimicrobial screening must be done before drugs are prescribed for enteric infections and/or infectious diarrhoea in developing countries.

The present study findings revealed that high frequencies of infectious diarrhoea in both children and adult were caused by antimicrobial resistant commensally gut bacteria, thus significantly representing the effect of established unregulated antimicrobial use. Enteric pathogens easily share genes for antimicrobial resistance; in addition to the continuous selective pressure applied by the over counter availability of these agents as well as the frequent prescription of those agents at health centres. A number of studies have demonstrated a high prevalence of MDR bacteria in normal bowel flora. These bacteria were suggested to act as a reservoir for resistance to enteric pathogens. In a study investigated the commensally gut flora of children. It was found that $39 \%$ of children had strains resistant to all antimicrobial agents tested and more than 70 $\%$ of the children had strains resistant to at least 4 of antimicrobials (Shears et al., 1988).

Plasmid profile analysis is a rapid and useful method for epidemiologic typing to follow the spread of the epidemic strain and may be more helpful than other typing methods (Mayer, 1988). The current study examined the plasmid profile of 40 selected MDR enteric bacterial isolates including $20 \mathrm{E}$. coli and $20 \mathrm{~K}$. pneumoniae isolates. This plasmid profile-based molecular characterization was carried out as a useful method to investigate microbial diversity among bacteria isolated in this study. It appears that plasmids are ubiquitous in this bacterial population, although different plasmid profiles were detected which coexisted in tested isolates. The plasmid analyses revealed that there were detectable plasmids in $31(77.5 \%)$ out the 40 isolates, while $9(22.5 \%)$ had no plasmids. In the isolates that harboring plasmids, about 10 different plasmids were 
detected with 15 isolates carrying from 2 to 6 plasmids. This finding is consistent with the finding of Fujita (1993) study which detected 31 plasmids in 14 of 45 MDR resistant enteric bacterial isolates with some isolates carrying 2 to 4 plasmids. Plasmid profile analysis could differentiate these selected isolates. This may reflect the presence of a large number of different endemic isolates or a high rate of plasmid transfer amongst isolates or both (Olukoya and Oni, 1990). The diverse patterns of plasmid profiles observed among isolates in the current study could be also due to higher exposure of people to enteric bacteria in these places with poor sanitation (Olukoya and Oni, 1990).

The different plasmid profiles detected in this study indicated that the MDR enteric bacteria comprised large number of clones within each species, which couldn't be elucidated by antimicrobial susceptibility testing alone. These findings are in agreement to the findings of a study conducted in Bangladesh by Tacket and Cohen (1983) which revealed that plasmid profiles differentiated enteric bacterial isolates. In the current study, all isolates that had plasmids were resistant to ampicillin, doxycycline, trimethoprim/sulfamethoxazole, gentamicin and chloramphenicol. Thus, the demonstration of high molecular weight plasmids in the isolates and the finding that these isolates are MDR could be plasmidmediated is significant. McPherson and Gealt (1986) revealed the relation of multidrug resistance of enteric bacterial pathogens and possessing high molecular weight plasmids, which could be transferred among bacteria. This transmissibility of resistance-mediated plasmids poses public health threat, which could be heightened if disseminated across countries by travelers (Chigor et al., 2010).
In conclusion, there is an alarming increase of infections diarrhoea caused by MDR bacteria. This study has revealed diverse plasmid profiles and wide spread of antimicrobial resistance patterns of some enteric bacterial pathogens from Cairo, Egypt. Thus, a public health policy on appropriate prescribing and the rational use of antimicrobial agents is a foundation. In addition, the implementation of periodic active surveillance for MDR enteric bacteria will be useful to monitor the changing epidemiology of these bacteria.

\section{References}

Akinnibosun, F.I., Nwafor, F.C. 2015. Prevalence of diarrhoea and antibiotic susceptibility test in children below 5 years at University of Benin Teaching Hospital, Nigeria. Int. Res. J. Public Environ. Health, 2(4): 49-55.

Alikhani, M.Y., Hashemi, S.H., Aslani, M.M., Farajnia, S. 2013. Prevalence and antibiotic resistance patterns of diarrheagenic Escherichia coli isolated from adolescents and adults in Hamedan, Western Iran. Iranian J. Microbiol., 5(1): 42.

Bauer A., Kirby W., Sherris J., Turck M. 1996. Antibiotic susceptibility testing by a standardized single disk method. American J. Clin. Pathol., 45(4): 493-496.

Boschi-Pinto C., Velebit L., Shibuya K. 2008. Estimating child mortality due to diarrhoea in developing countries. Bull. World Health Organ., 86(9): 710-7.

Brooks, G.F., Carroll, K.C., Butel, J.S., Morse, S.A. 1991. Enteric Gram-Negative Rods (Enterobacteriaceae) Pages 212-223 in Jawetz, Meinick \& Adelberg Medical Microbiology $19^{\text {th }}$ ed. Appleot and Lange Companies, Inc.

Carpenter, C.J. 1989. Diarrheal disease caused by Escherichia coli Pages 698-703.in Hoeprich P. D. and Jordan M. C. (Chief editors) Infectious diseases, a modern treatise of infectious processes. $4^{\text {th }}$ ed. J. B. Lippincott Co. Philadelphia. U.S.A. 
Chigor, V.N., Umoh, V.J., Smith, S.I., Igbinosa, E.O., Okoh, A.I. 2010. Multidrug resistance and plasmid patterns of Escherichia coli $\mathrm{O} 157$ and other E. coli isolated from diarrhoeal stools and surface waters from some selected sources in Zaria, Nigeria. Int. J. Environ. Res. Pub. Health, 7(10): 3831-3841.

CLSI. 2014. Performance Standards for Antimicrobial Susceptibility Testing; $24^{\text {th }}$ informational Supplement. CLSI document M100-S24. Pages: 50-57.

Collins, S. 2007. Treating severe acute malnutrition seriously. Arch. Dis. Childhood, 92(5): 453-461.

Diniz-Santos, D.R., Silva, L.R., Silva, N. 2006. Antibiotics for the empirical treatment of acute infectious diarrhea in children. Brazilian J. Infect. Dis., 10(3): 217-227.

El-Gilany, A.H., Hammad, S. 2005. Epidemiology of diarrheal disease among children under five years in Dakahalia, Egypt. Eastern Mediterranean Health J., 11(4): 765.

Fujita, M., Ike, M., Suzuki, H. 1993. Screening of plasmids from wastewater bacteria. Water Res., 27(6): 949-953.

Gómez-Duarte, O.G., Arzuza, O., Urbina, D., Bai, J., Guerra, J., Montes, O., Puello, M., Mendoza, K., Castro, G.Y. 2010. Detection of Escherichia coli enteropathogens by multiplex polymerase chain reaction from children's diarrheal stools in two Caribbean-Colombian cities. Foodborne Pathogens Dis., 7(2): 199-206.

Hart, C.A., Batt, R.M., Saunders, J.R. 1993. Diarrhea caused by Escherichia coli. Ann. Trop. Pediat., 13(2): 121-131.

Huttner, B., Haustein, T., Uckay, I., Renzi, G., Stewardson, A., 'le Schaerrer, D., Agostinho, A., Andremont, A., Schrenzel, J., Pittet, D., Harbarth, S. 2013. Decolonization of intestinal carriage of extended-spectrum $\beta$-lactamase-producing Enterobacteriaceae with oral colistin and neomycin: a randomized, double-blind, placebo-controlled trial. J. Antimicrob. Chemother., 68: 2375-2382.
Jindal, N., Arora, S., Arora, R. 1995. Enterotoxigenic enteric bacteria causing secretory diarrhea. Ind. J. Pathol. Microbiol., 38(2): 177-180.

Magiorakos, A.P., Srinivasan, A., Carey, R.B., Carmeli, Y., Falagas, M.E., Giske, C.G., Harbarth, S., Hindler, J.F., Kahlmeter, G., Olsson-Liljequist, B., Paterson, D.L. 2012. Multidrug-resistant, extensively drug-resistant and pandrug-resistant bacteria: an international expert proposal for interim standard definitions for acquired resistance. Clin. Microbiol. Infection, 18(3): 268-281.

Mayer, L.W. 1988. Use of plasmid profiles in epidemiologic surveillance of disease outbreaks and in tracing the transmission of antibiotic resistance. Clin. Microbiol. Rev., 1(2): 228-243.

McPherson, P.H.I.L.I.P., Gealt, M.A. 1986. Isolation of indigenous wastewater bacterial strains capable of mobilizing plasmid pBR325. Appl. Environ. Microbiol., 51(5): 904-909.

Miller, P.C. 1992. Trends in the management of childhood diarrhoea in Egypt: 1979-1990. J. Diarrhoeal Dis. Res., 10: 193-200.

Murray, P.R., Baron, E.J. 2007. Manual of clinical microbiology. Washington, D.C., ASM Press.

Nguyen, T., Le Van, P., Le, C., Weintraub, A. 2005. Antibiotic resistance in diarrheagenic Escherichia coli and strains isolated from children in Hanoi, Vietnam. Antimicrobial Agents Chemother., 49 (2): 816-819.

Ochoa, T.J., Ruiz, J., Molina, M., Del Valle, L.J., Vargas, M., Gil, A.I., Ecker, L., Barletta, F., Hall, E., Cleary, T.G., Lanata, C.F. 2009. High frequency of antimicrobial drug resistance of diarrheagenic Escherichia coli in infants in Peru. Am. J. Trop. Med. Hyg., 81(2): 296301.

Olowe, O.A., Olayemi, A.B., Eniola, K.I.T., Adeyeba, O.A. 2003. Aetiological agents of diarrhoea in children under five years of age in Osogbo, Osun State. African $J$. Clin. Experimental Microbiol., 4(2): 6266. 
Olukoya, K., Oni, O. 1990. Plasmid profile analysis and antimicrobial susceptibility patterns of Shigella isolates from Nigeria. Epidemiol. Infect., 105(1): 59-64.

Putnam, S.D., Riddle, M.S., Wierzba, T.F., Pittner, B.T., Elyazeed, R.A., El-Gendy, A., Rao, M.R., Clemens, J.D., Frenck, R.W. 2004. Antimicrobial susceptibility trends among Escherichia coli and Shigella spp. isolated from rural Egyptian pediatric populations with diarrhoea between 1995 and 2000. Clin. Microbiol. Infection, 10(9): 804-810.

Qadri, F., Svennerholm, A.M., Faruque, A.S., Sack, R.B. 2005. Enterotoxigenic Escherichia coli in developing countries: epidemiology, microbiology, clinical features, treatment, and prevention. Clin. Microbiol. Rev., 18(3): 465-483.

Sang, W.K., Oundo, V., Schnabel, D. 2012. Prevalence and antibiotic resistance of bacterial pathogens isolated from childhood diarrhoea in four provinces of Kenya. J. Infection in Developing Countries, 6(7): 572-578.

Sankaran, N. 2000. Microbes and People an A-Z of Microorganisms in Our Lives. Phoenix, Az.: Oryx Press.

Shears, P., Suliman, G., Hart, C.A. 1988. Occurrence of multiple antibiotic resistance and $\mathrm{R}$ plasmids in
Enterobacteriaceae isolated from children in the Sudan. Epidemiol Infect., 100(1): 73-81.

Tacket, C.O., Cohen, M.L. 1983. Shigellosis in day care centers: use of plasmid analysis to assess control measures. Pediatr. Infect. Dis. J., 2(2): 127-130.

Temu, M.M., Kaatano, G.M., Miyaye, N.D., Buhalata, S.N., Shushu, M.L., Kishamawe, C., Changalucha, J.M. 2007. Antimicrobial susceptibility of Shigella flexneri and $S$. dysenteriae isolated from stool specimens of patients with bloody diarrhoea in Mwanza, Tanzania. Tanzan Health Res. Bull., 9(3): 186-189.

Winn, W.C., Koneman, E.W. 2006. Koneman's color atlas and textbook of diagnostic microbiology. Philadelphia, Lippincott Williams \& Wilkins.

World health organization. 2014. Antimicrobial resistance: Global report on surveillance 2014, http://www.who.int/drugresistance/ docum ents/surveillancereport/en/ last reviewed February 10, 2016.

Yah, S.C., Chineye, H.C., Eghafona, N.O. 2007. Multi-antibiotics-resistance plasmid profile of enteric pathogens in pediatric patients from Nigeria. Biokemistri., 19(1): $35-42$.

\section{How to cite this article:}

Abdel-Nasser A. El-Moghazy, Mahmoud M. Tawfick and Mahmoud M. El-Habibi. 2016. Prevalence, Antimicrobial Susceptibilities and Molecular Characterization of Enteric Bacterial Pathogens Isolated from Patients with Infectious Diarrhoea in Cairo, Egypt. Int.J.Curr.Microbiol.App.Sci.5(4): 553-564. doi: http://dx.doi.org/10.20546/ijcmas.2016.504.063 